\title{
THE BACTERIOLOGICAL FINDINDINGS BETWEEN THE MIDDLE EAR AND THE PHARYNX IN CASES OF ACUTE SUPPURATIVE OTITIS MEDIA
}

\author{
RINYA SUGITA, M. D., GINICHIRO ICHIKAWA, M. D., \\ TOSHIO UCHIDA, M. D., SHIGEO GOTO, M. D. \\ Juntendo University School of Medicine Department of Otolaryngology.
}

(Director: S. Kawamura M. D.)

The clinical and bacteriological data of 61 cases of the acute otitis media were presented The bacteriological correlation between the middle ear and the nasopharynx and oropharynx was studied; all of the cases were subjected to the studies on bacteria of the ear and of the nasopharynx and the oropharynx.

The results are as follows:

1) Sixty-four strains of bacteria were isclated from 61 middle ear effusions. Streptococcus pneumoniae was $64 \%$ of the strain, $i$. influenzae was $19 \%$, beta-hemolytic streptococcus was $6 \%$ and Staphylococcus auri. ws was $11 \%$.

2) There were 70 strains of potential pathogen isolited from the nasopharynx.

Streptococcus pneumoniae was $i 9 \%, \mathrm{H}$. influenzae was $19 \%$, beta hemolytic streptococcus was $6 \%$ and staphylococeus aureus $16 \%$.

3) There were $6 \%$ strains of potential pathogen isolated from oropharynx.

Streptococcus one: roniae was $50 \%, \mathrm{H}$. influenzae was $15 \%$, beta-hemolytic streptococcus was $15 \%$, star: 4, ccus aureus was $19 \%$ and Klebsiella pneumoniae was $1.5 \%$.

4) The briturulugic correlations between the ear and the nasopharynx are as follows:

Corrolete agreement, $72 \%$ of the cases; partial agreement, $20 \%$; and disagreement, $8 \%$.

5) The bacteriologic correlations between the ear and the oropharynx are as follows:

Complete agreement, $42 \%$ of the cases; partial agreement, $26 \%$; and disagrrment, $25 \%$.

6) There is an extreme difference in the agreement rate between the nasopharynx and the oropharynx. Statistically, Chi-square test showed that the nasopharynx has a greater similarity to middle ear than the oropharynx in bacteria at the .05 level of significance.

7) The coincident rate of bacteria between middle ear and nasopharynx are as follows:

Streptococcus pneumoniae, $97 \%$ of cases; $\mathrm{H}$. influeuzae and beta hemolytic streptococcus, $100 \%$; and staphylococcus aureus, $20 \%$. 


\title{
河村正三教授開講 10 周年記念論文
}

\section{急性化膿性中耳炎の中耳と咽頭各部との細菌の関係について}

\author{
顺天堂大学医学部耳鼻哂喉科学教室（主任：河村正三教授）

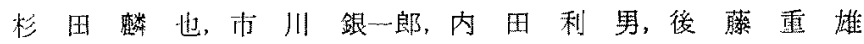

Iはじめに

急性化滕性中耳炎は，副舅踛炎，咽頭炎なジ上気 道の炎症にひきつついて発症すること加非常に多い，艺 れは，中耳腔と㸶頭とが耳管を介してつながっているた めである。したがって，急性化滕性中耳资患者の中耳院 と咽頭との間には密接な細菌学的関係のあることが推剆 される。

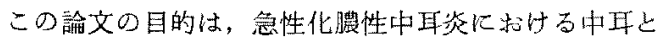
咽頭各部とのつながりを細菌学的な面から検討すること にある.そして，いちがいに咽頭といっても，そのうち のいずれの部位が中耳に強い影響を与えているのかを明 らかにすることにある。

\section{II 対 象}

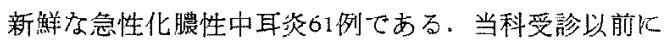
他の医療機関ですで治療をうけていたり，経過が長い もの，発症の時期泣はっりしない症例は対象加ら除外 した.

年齢分布は 5 歳末洅 $46.7 \%, 6 \sim 10$ 歲 $31.7 \%, 11 \sim$ 15歳 $11.7 \% ， 16$ 歳以上 $10 \%$ でった。

\section{III 研 究方 法}

病歴如よび局所々胃加ら急性化澧性中耳资と診断した 61名のうち，57名に初診時飞鼓膜切開を和こなった。て して，流出した中耳眝溜液を滅菌綿棒で採取した。 初診時にすでに耳漏が流出していた 4 例は外耳道儿ある 耳漏をるさとり，できるだけ鼓膜近くかあるいは穿孔部

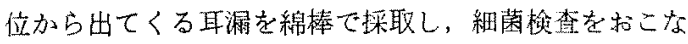
った.

上咽頭からは，舌を舌王子で押光先端を $90^{\circ}$ 近く曲げ た滅菌綿棒を経口舵的に患耳側の上咽頭に挿入し，上咽 頭粘液を強くこすりとった。

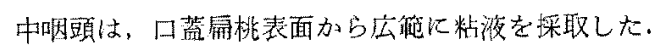

細菌検查は、耳、漏括よび咽頭粘液のいずれも好気性 菌，嫌気性菌培荃を括こなった，培地は，表!のごとく 好気性菌 4 種，嫌気性菌 3 種，增菌用 2 種を常用した。 㛺苝時間は好気性菌は一夜，积気性菌は GAS PACK 法を使用し原則として48時間まで実施した。そして，コ

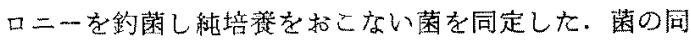
定仙主に Bergey's Manual 飞徒って実施した.

表 1 細囷検查に使用した培地

好気性菌: ヒツジ血液加寒天培地 (BA)

フェニールエチールアルコール培地(PEA)

チョコレート寒天培地

トリガルスキ一改良培地 (BTB)

嫨気性菌：フェニールエチールアルコール培地

リバビール寒天倍地

GAM 舆天培地

増薂用: 臨床用于オグリコレ一ト液体培地

GAM 半流動高是培地

\section{IV 䑩 果}

中耳之咽頭各部のまな細菌の検出率をまとあて表 2 K 亦した。

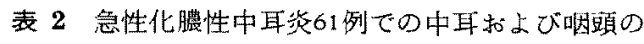
主な菌检出率

\begin{tabular}{|c|c|c|c|}
\hline & 中耷 & $\frac{\text { 上咽潩 }}{(70 \text { 株) }}$ & $\begin{array}{l}\text { 中咽頭 } \\
\text { (67怢) }\end{array}$ \\
\hline 脚炎球菌 & $60.9 \%$ & $59 \%$ & $50 \%$ \\
\hline インフルエンザ畄 & 18.7 & 19 & 15 \\
\hline 溶血軽鎖球菌 & 6.3 & 6 & 5 \\
\hline 黄色ブドウ球菌 & 10.9 & 16 & 19 \\
\hline その他 & 3.1 & - & 1.5 \\
\hline$-\cdots$ & & 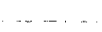 & \\
\hline
\end{tabular}


な特，本墖文では次のような細菌を咽頚の常在菌とし 菌検出率の成績には加えなかった。なかb， $\alpha$ 抢よび

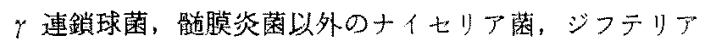
菌以外のコリネバクテリウムインンフエンザ菌以外の ヘモフイリス，嫌気性菌では Veillonella, Bacteroides などである。

1) 中耳加b0主な検由菌

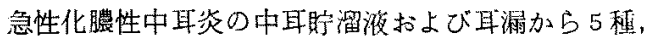

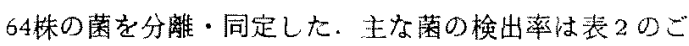
とく, 脯炎球菌 64\%，インフルエンザ菌 19\%，溶追連 鎖球菌 6\%および黄色ブドウ球菌 $11 \%$ などであった。

2) 咽頭からの主な検出菌

(1)上咽頭加占は上述した常在菌老除外して，70株を 分離同定した。 それらは，肺资球菌 $59 \%$ ，1ンフルエ ンザ菌 $19 \%$ ，溶血連鎖球菌 $6 \%$ ，黄色ブドウ球菌 $16 \%$ であった.

(2) 中咽頭からは常在菌を除外して67怢を分解同定し た。そのらちわけは，肺炎球菌 50\%，インフルエンザ 菌 $15 \%$ ，溶血連鎖球菌 $15 \%$ ，黄色ブドウ球菌 $19 \%$, 肺资桿菌 $1.5 \%$ であった。

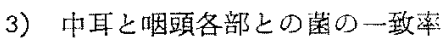

中耳と上咽頭および中咽頭との細蔽の一致染老まとめ て図1に示した。

完全一致とは，中耳と咽頭と加ら同じ種類の菌を検出 した場合である。咽頭からは中耳炎の原因となりらる菌 の他に，上述した咽頭の常在菌を一緒に検出することが しはしばあった、だが、これらの常任菌は中耳と咽頭と の菌の比較の対家から陈外した，例えば，中耳から脚炎 球菌，咽頭から肺贸球菌と $\gamma$-Streptococcus 老梌出して も $\gamma$-Streptococcus は咽頍の定住掌在菌てあるので完全 一致应例とした。

部分一致亡は，中耳から肺资球菌と黄色ブドウ球菌，

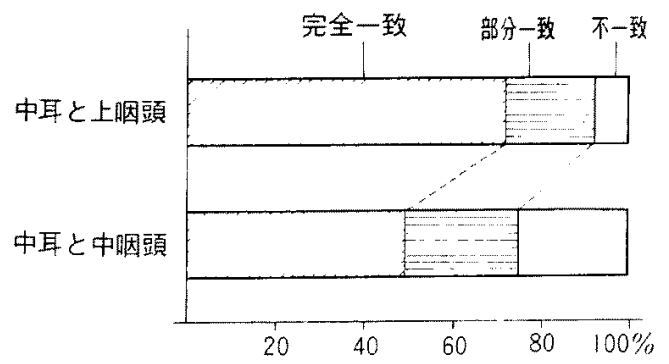

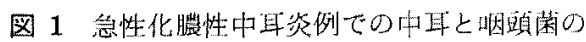
一致率

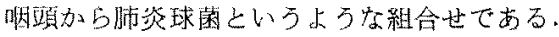

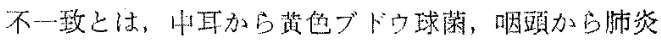
球菌上いうように，西都加ら全く異なる菌を检出した場

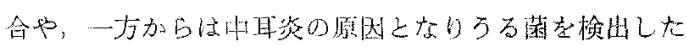

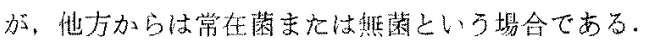

このような条件のもとでの中耳之上咽頭との菌の夙係 は，完全一票 $72 \%$ ，部分一政 $20 \%$ ，不一致 $8 \%$ であ。 た。また，中耳と中咽頭とでは，省全一致 $49 \%$ ，部分 㮹 $26 \%$, 不一致 $25 \%$ あっった。

\section{$\mathrm{V}$ 芳 察}

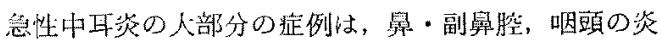
拝なとにつついて発症する。いままで疫学的な報告を 引り加えると, Davison ${ }^{1)}$ 仕急性中耳炎をくり加党して

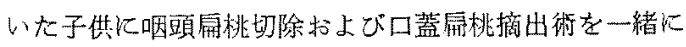

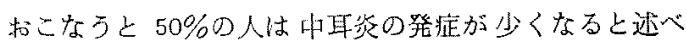

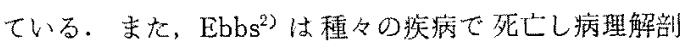

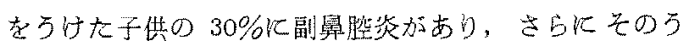
ちの $79 \%$ 壮中耳资羅患の経娩在していたと報告して いる.

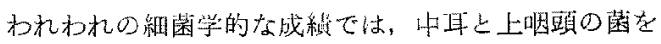
比較すると完全一致末よび部分一致をらくめて92\%の

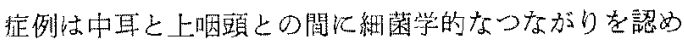
た.だが，中耳と中䀩頭との間には $75 \%$ 症例でしか つながりを証明できなかった，完全一致だけでは $23 \%$ ， 部分一致までらくめると $27 \%$ あの一致率の差があった。 この差们ついて $\mathrm{x}^{2}$ 検定を扰しなったところ， $\mathrm{x}^{2}=5.57$ $>3.84$ で $5 \%$ の危険率で有望の差があることが確認さ れた，そして，完全一致たけでく，完全一致と部分 致を古わせたものでも同様な結果を得た。この結果は， 耳管加開曰している部位加らす机むしる当然というべ きかもしれないが，細菌学的な面からも上咽頭の方が中 咽頭よりも中耳との菌の関係が深いことを立証したとい 光る。

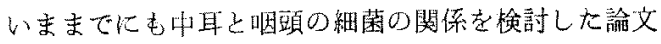

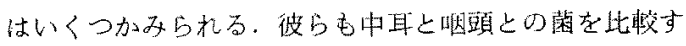

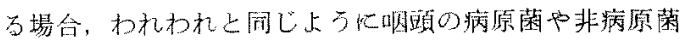

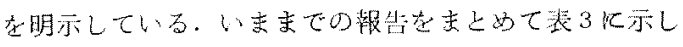

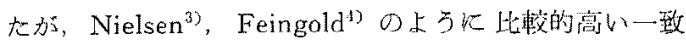

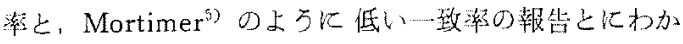

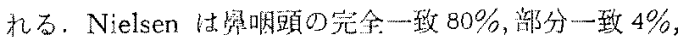

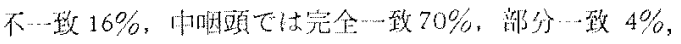

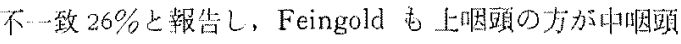


表 3 中耳と咽頭との菌の閔係の文献

\begin{tabular}{|c|c|c|c|c|c|}
\hline & 報告者 & $\begin{array}{c}\text { Nielsen } \\
1945\end{array}$ & $\begin{array}{l}\text { Mortimer } \\
1956\end{array}$ & $\begin{array}{c}\text { Feingold } \\
1966\end{array}$ & $\begin{array}{l}\text { 箵者 } \\
1978\end{array}$ \\
\hline 上 & 症例 数 & 285 & 36 & 35 & 61 \\
\hline \multirow{3}{*}{$\begin{array}{l}\text { 咽 } \\
\text { 頭 }\end{array}$} & 完全一票 & $80.4 \%$ & $38.9 \%$ & $69 \%$ & $72 \%$ \\
\hline & 部分一致 & 3.5 & 30.6 & & 20 \\
\hline & 本…数 & 16.1 & 30.6 & & 8 \\
\hline 中 & 症 例 数 & 285 & 33 & 38 & 61 \\
\hline 咀 & 完全一票 & $69.8 \%$ & $36.4 \%$ & $40 \%$ & $49 \%$ \\
\hline \multirow{2}{*}{ 頭 } & 部分一致 & 3.5 & 51.5 & & 26 \\
\hline & 不一致 & 26.7 & 12.1 & & 25 \\
\hline
\end{tabular}

より毛中耳との一致率が高いと述へている。これに対し て、Mortimer は中咽頭の完全一致 $36 \%$, 部分一致 52 $\%$ ，不一致 $12 \%$ ，上哂頭の完全一致 $39 \%$ ，部分一致 $31 \%$ ，不一致 $31 \%$ とし，中咽頭の方が上咽頭よりも中耳 との関係加やや深い成績を発表している。

上咽頭と中咽頭とでは耳管との距離的な差はあまりな い上ろに思われるのに中耳之の菌の一致率にわ水われが 報告したよう度が生ずる原因は，何迀であるう 力.

ます，咽頭各部の菌検出率をみると，肺资球菌，溶血

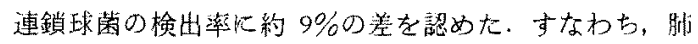
炎球菌は上时頭で，溶血連鎖球菌は中咽頭での检出率が 高い。

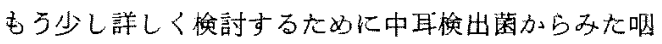
頭各部加のの检出菌上の一致率をみてみた。その結果 は，表 4，5K示したよ弓K，中耳之上咽頭とでは一要 率は $87.5 \%$ であり囷種别には肺炎球菌 $97.4 \%$ ，インフ ルエンザ菌，溶血連鎖球菌 $100 \%$ で，黄色ブドウ球菌は $28.6 \%$ であった．中耳と中因頭の一至率は $72.6 \%$ であ り，菌種别には肺粐球菌 $74.4 \%$, 溶血連鎖球菌，1ン フルエンザ菌 100\%，黄色ブドウ球菌 20\%であった。 これらの成綪から，上咽頭と中咽頭との一致率の差は肺 炎球菌の検出率のちがいが一因上思就れた。

咽頭の䔃菌についていままでの報告をらりかえると，

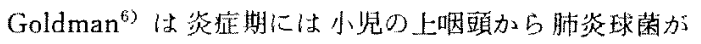
検出されることが多く，非炎症時には $1 \%$ 未满てしか梌 出されず上咽頭资での肺资球菌の重要性を報告してい

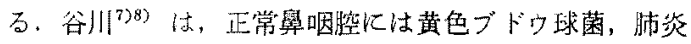
球菌が全くみあたらず，これらが高率に諗められると買
表 4 中耳検出菌加方みた上咽頭検出菌との一政率

\begin{tabular}{|c|c|c|c|}
\hline & - 致 & 不一般 & 合 部 \\
\hline 肺资球菌 & $\begin{array}{c}38 \text { 株 } \\
97.4(\%)\end{array}$ & $\begin{array}{c}1 \text { 铢 } \\
2.6(\%)\end{array}$ & 39 株 \\
\hline インフルエンザ凩 & $\begin{array}{r}12 \\
100\end{array}$ & 0 & 12 \\
\hline 溶血連鎖球菌 & $\begin{array}{r}4 \\
100\end{array}$ & 0 & 4 \\
\hline 黄色ブドウ球菌 & $\begin{array}{r}2 \\
28.6\end{array}$ & $\begin{array}{r}5 \\
71.4\end{array}$ & 7 \\
\hline 亥仅ブドウ球菌 & $\begin{array}{l}0 \\
0\end{array}$ & $\begin{array}{r}2 \\
100\end{array}$ & 2 \\
\hline 盒䛨 & $\begin{array}{c}56 \text { 朴 } \\
87.5(\%)\end{array}$ & $\begin{array}{c}8 \text { 柁 } \\
12.5(\%)\end{array}$ & 646 \\
\hline
\end{tabular}

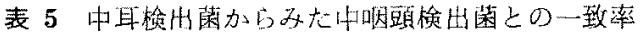

\begin{tabular}{|c|c|c|c|}
\hline & 一 政 & 不一致 & 台 部 \\
\hline 肺资球菌 & $\begin{array}{c}326 \text { 株 } \\
74.4(\%)\end{array}$ & $\begin{array}{c}11 \text { 株 } \\
25.6(\%)\end{array}$ & 43 棅 \\
\hline 1ンフルエンザ畕 & $\begin{array}{r}8 \\
100\end{array}$ & - & 8 \\
\hline 缩血連鎖球菌 & $\begin{array}{r}4 \\
100\end{array}$ & - & 4 \\
\hline 共色ブドり球菌 & $\begin{array}{r}1 \\
20\end{array}$ & $\begin{array}{r}4 \\
30\end{array}$ & 5 \\
\hline 表伎ブドウ球菌 & - & $\begin{array}{r}2 \\
100\end{array}$ & 2 \\
\hline 弇部 & $\begin{array}{c}45 \text { 株 } \\
72.6(\%)\end{array}$ & $\begin{array}{c}17 \text { 株 } \\
27.4(\%)\end{array}$ & 62 怢 \\
\hline
\end{tabular}

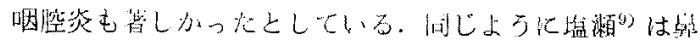

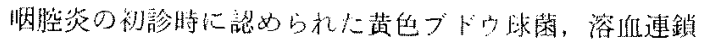

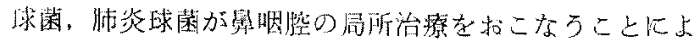

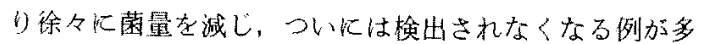

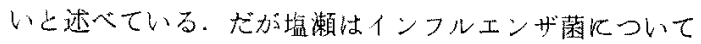
は全くふれていない，いずれの郝告でも上咽頭篹の上き

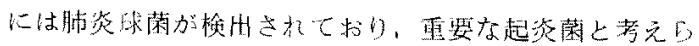
机万。

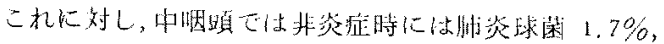

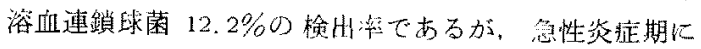

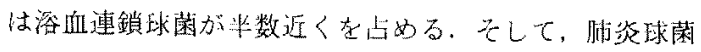
は蔣 ${ }^{10\rangle} 0 \%$, 中村 ${ }^{112} 0 \%$, 杉田 ${ }^{12) 13\rangle} 6 \%$ 上報告している。 
肺资球菌は中咽頭に限局した资症の場合はあまり重要な 役割を演していない。

今回の急性化膿性中耳炎の上咽頭で结 $60 \%$, 中咽頭 では 50\%の肺资球菌検出率であった，この成績からは， 肺炎球菌が中咽頭の炎症上決して無関係ではないように 思われる、このちがいは，口蓋凩桃炎のようなリンパ組 機の定と，風邪のよらなびまん性の上気道粘膜の资症 とでは起炎菌がことなるのであるうか。

Goldman $^{6)}$ は健康人の畄咽腔は病気の carrier-focus でありそこに接している中耳，副鼻脘，気管支一炎症が 広がると述べている。したがって，はじめは上咽頭に限 局していた䔉む中耳炎発症の頃には中咽頭まで広がった と考元られば，急性中耳炎症例の上咽頭と中咽頭之か 5 の肺炎球菌検出率加似ていても招かしくない。

次に，部分一致症例の内容を検討する。部分一致例は 一致であある半面，不一致であおる．従って，部分一致 の不一致面を部分的不一致とよ忍ことにする。部分的不 一致の原因は表6のごとくで，上咽頭では $83 \%$ 黄色 ブドウ球菌，中咽頭ては $75 \%$ が黄色ブ菌であり，牫り

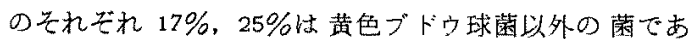
っ.

これをもう少し詳くみるために部分的不一形の原因を 中耳と㸶頭とにわけて示した（表7，表 8). 中耳と上咽 頭では，中耳から検出した黄色ブドウ球菌が原因の場合 が2例であった。上咽頭の菌が原因の場合が10例でその 大部分は黄色ブドウ球菌であった。中耳と中国頭との比 較で中耳が原因の6のが15例中 1 例 $(6.7 \%)$ で菌は黄色 ブドウ球菌であった。中咽頭が原因の場合は15例中14例 (93.3\%) でそのうちの10例（71\%）㬏色ブドウ球菌 であった。そして残りは，溶血連鎖球菌 2 例，インフル エンザ菌および肺炎桿菌各1例てあった，部分的不一致 の原因となった細菌は，黄色ブドウ球菌が8割強を占め t.

最後に不一致例の内容をまとめて表9に示した。完全 不一致の菌の組合せは3種類あった。すなわ，中耳去 び咽頭加ら異なる病原菌を検出した組合せの場合が上咽 頭，中咽頭各 1 例ずつあった，中耳から病原菌を検出し たが咽頭からは常在菌だけの場合が上㸶頚 1 例，中咽頭

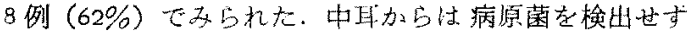
咽頭加ら病原菌を検出した場合が上咽頭で 3 例 (60\%)， 中咽頭 4 例 $(31 \%)$ であった.

多、原因をみる上，中耳加ら病原菌（一）で喟頭加ら

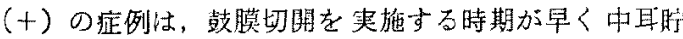

表 6 中耳之咽頭の菌の関係 部分一致症例 $\sigma$ 検討

\begin{tabular}{|c|c|c|c|c|}
\hline & 菡 種 & 上咽頭12例 & \multicolumn{2}{|c|}{ 中咽頭15例 } \\
\hline \multirow{3}{*}{ 一票部分 } & 肺炎球菌 & 10 制 & $12 t$ & \\
\hline & $\begin{array}{l}\text { インフルエンザ } \\
\text { 菌 }\end{array}$ & 2 株 & 2 & \\
\hline & 溶血連鎖球菌 & - & 1 & \\
\hline \multirow[t]{2}{*}{ 不一敨部分 } & 蒉色ブドウ球菌 & 10 株 $83.3 \%$ & 12 & $75 \%$ \\
\hline & $\begin{array}{l}\text { 黄色ブドウ球菌 } \\
\text { 以外の病原菌 }\end{array}$ & 2 株 $16.9 \%$ & 4 & $25 \%$ \\
\hline
\end{tabular}

表 7 部分一致症例の検討

\begin{tabular}{|c|c|c|}
\hline & \multicolumn{2}{|c|}{ 部分的不一致の原因 } \\
\hline & 中 早 & 上咽䫒 \\
\hline 脯 炎 球 箱 & ○株 & 1 株 \\
\hline インフルエンザ圂 & o & 1 \\
\hline 黄色ブドウ球菌 & 2 & 8 \\
\hline 合 & 2 & 10 \\
\hline
\end{tabular}

表 8 部分一致症例の㭘討 中耳耷之中咽頭之の菌の四侨

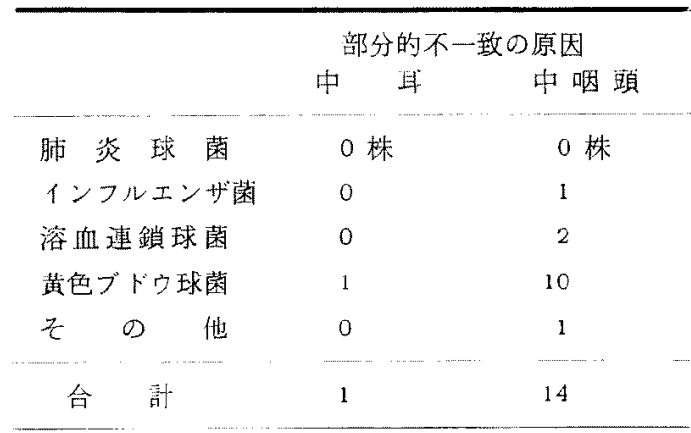

表 9 不一致症例の梌詰

\begin{tabular}{|c|c|c|c|c|}
\hline \multicolumn{3}{|c|}{ 菌の組合せ } & \multirow{2}{*}{ 上咽頭 } & \multirow{2}{*}{ 中咽頭 } \\
\hline 中 & 耳 & 咱 頭 & & \\
\hline \multicolumn{3}{|c|}{ 跨原菌 $(+)$ 一病原畨 $(+)$} & 1 例 & 1 例 \\
\hline \multicolumn{3}{|c|}{ 病原菌(+)一病原藏 $(-)$} & 1 & 8 \\
\hline \multicolumn{3}{|c|}{ 病原菌 $(-)$ 一病原菌 $(+)$} & 3 & 4 \\
\hline & 合 & $\overrightarrow{\bar{t}}+$ & 5 & 13 \\
\hline
\end{tabular}


溜腹が流山してこない昜合が大部分であった。また，中 耳加巨病原菌 (十) で咀頭加 ら (一) の症例は，菌の採 取の問題や，囷数が少ないため㑑体の防街反応ですで

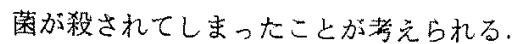

中耳特よび因頭加ら别々の菌を梌出した怔例は中耳出 ら黄色ブドウ球菌，表皮ブドウ球菌で，咽頭からはいず

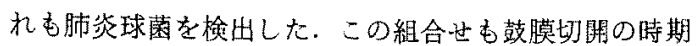
や，技術的な問題が原因であらう。

急性化颉性中耳炎の起茨菌については，别稿で梌討し 先に報告した ${ }^{14}$ が，今回の椧討からも急性中耳炎から検 出される黄色ブドウ球菌の意味について大きな疑問が持 たれた、また，今回の研究から，急性化膿性中耳炎に特 に強い影響索与える解剖学的部位は上咽頭であることを 細菌学的な面加再確認した. そして, 念性中耳炎の治 療は，中耳のみならず鼻腔，上咽頭などの十分な治療が 不可久であることを知った。

\section{ま Łめ}

1. 新鮮な急性化腆性中耳炎61例を対象として中耳と 上咽頭，中咽頭の3 力所の細菌を比較した. そして，中 耳资人の时頭の影僔を細菌学的な面加ら検討した。

2.上咽頭の方が中咽頭よりも中耳との一票率が高か った. 統計学的にも $\mathrm{x}^{2}$ 検定で $5 \%$ の危绘率で一教率に 有意差のあることが確認された。

3.中耳検出菌加らみ大中耳上上咽頭上の一致率は, 肺炎球菌 97\%，インフルエンザ菌扎よび溶血連鎖球菌 100\%と非常に㽞加った：これに对して，黄色ブドウ球 菌 29\%ときかめて低い一敖率であった。

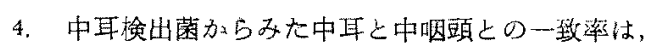
インフルエンザ蔽および溶血連鎖球菌 $100 \%$, 胡炎球菌 74\%，黄色ブド球菌 $20 \%$ でった。

5. 部分一致例は一致と不一致の部分加ら構成される が不一致の部分の原因䔉は黄色ブドウ球菌が大部分を占 めた.

6. 中耳および上咽頭加ら共通の菌を俗出しても，中 咽頭から呐頭の常在菌だけしか检出しないこしがしは しばあった。

7. 本邦の急性中耳炎検出图に関する報告では黄色ブ トり球菌および表皮ブドウ球菌の検出率が高い，だが，

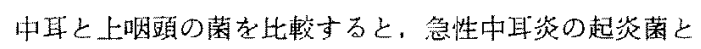
して黄色ブトウ球菌考考えことに性大きな疑問が委た れた。

\section{苶荟 献}

1) Davison $F W$ : Prevention of recurrent otitis media in children. Ann Otolaryngol 75: 735745, 1966.

2) Ebbs $J H$ : A note on the incidence of sinusitis in children. Brit Med J 1: 385- , 1938. 15) 上り引用

3) Nielsen $J H$ : Studies of the aetiology of acute otitis media. Ejnar Munksgaard, Copenhagen, 1945.

4) Feingold $M$ et al: Acute otitis media in children. Amer J Dis Child 111: 361-365, 1966.

5) Mortimer $E A$ et al: A bacteriologic investigation of otitis media in infancy. Pediatrics 17: 359-367, 1956.

6) Goldman $J L$ et al: bacteriologic and clinical interpretation of the flora of the nose and nasopharynx in children. J. Pediatrics 44: 299-303, 1954.

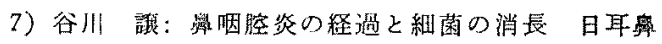
67: 613-620, 1964.

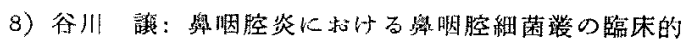
这びに夷駼的研染，日耳率 68：1579-1591， 1965.

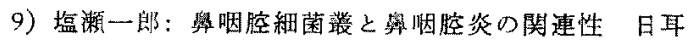
鼠 71: 1023-1035, 1968.

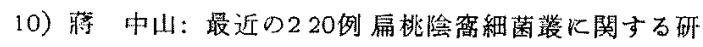
究 耳鵕㗐床 69: 19-33, 1976.

11) 中村正弥化：急性扁桃资の細菌学的矿究 遁信医 学 25: 367-376, 1973 .

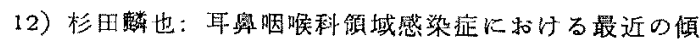
问论ついて 順天堂医学 24: 284-290, 1978.

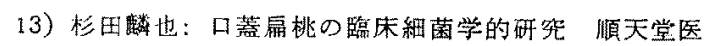
学 $25 ; 60-65,1979$.

14）杉田麟也，他：急性化澧性中耳资の起炎菌 日耳奥 $82 ; 568-573,1979$.

15) Davison $F W$ : nasal disease as a cause of otitis media, otitis media, 69-78, Chales $C$ Thomas, Springfield, 1972.

稿を終るにのそみ御指導，御稿閲をいたたきました恩 缉河村下三教授に心上り感謝いたします。

本研究に䅂始御協力いただきした順天堂大学附属医

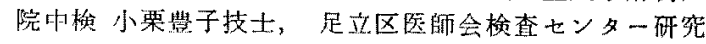
部出口浩一氏に感謝の意を表します。

$$
\text { （原稿悬付 沵和54.2.21日) }
$$

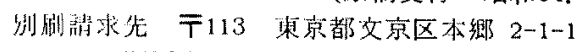
順天堂大学医学部耳显㸶㬋科学教室杉田麟也 